\title{
Cøliaki hos barn - nye retningslinjer
}

\author{
Nye norske retningslinjer er utarbeidet for diagnostikk og oppfølging av cøliaki hos barn, på grunnlag \\ av europeiske retningslinjer fra 2012.
}

\begin{abstract}
Dagens diagnostikk er helt avhengig av fortsatt inntak av gluten, men dessverre er noen pasienter og leger for ivrige med å kutte ut gluten før endelig diagnose. Både blodprøver og biopsier blir normale i løpet av kort tid på glutenfri kost. Derfor er det helt avgjørende at man venter med kostendring inntil spesialistutredning er gjennomført. Gjeninnføring av glutenholdig kost kan oppleves som en belastning for barnet og familien, og kan unngås dersom utredningen gjøres på riktig måte. I tvilstilfeller hender det fortsatt at glutenprovokasjon er nødvendig på et senere tidspunkt, men langt de fleste med cøliaki kan få sikker diagnose avklart hos barnelege.
\end{abstract}

\section{Biopsi eller blodprøver?}

Etter eldre retningslinjer har tynntarmsbiopsi og typiske histologiske forandringer vært hjørnesteinen i diagnostikk av cøliaki $(1,2)$. Tidligere tiders kapselbiopsi er blitt erstattet av endoskopisk biopsi, som hos barn gjøres i lett narkose. Fra å ta biopsi på tre ulike tidspunkter (1) er diagnosen siden 1990 blitt basert på en biopsi ved diagnose og gjentatt bare ved tvilstilfeller (2). Samtidig har nye generasjoner av antistofftester vist høyere spesifisitet og sensitivitet enn tidligere metoder, målt mot histologiske forandringer som gullstandard. Nå måles antistoff mot vevstransglutaminase (tTG2), eventuelt supplert med antistoff mot deamidert glutenpeptid (DGP) (3).

Dette er bakgrunnen for at de nye retningslinjene har åpnet for at barn med klassiske symptomer og antistofftiter forhøyet til mer enn ti ganger øvre grense kan få diagnosen uten biopsi (3). Hos omkring halvparten av barn med cøliaki er disse kriteriene ikke oppfylt, slik at biopsi fortsatt er nødvendig (4). Hvilke symptomer som skal defineres som klassiske, er omstridt, fordi cøliaki kan gi et vidt spekter av symptomer som forekommer hyppig hos barn uten tilstanden (5). De nye retningslinjene inneholder også kriterier for å stille diagnosen uten biopsi.

\section{Supplerende tester}

Endomysiumtest har tidligere vært sentral i diagnostikk av cøliaki. Denne testen er mer arbeidskrevende og mindre standardisert enn måling av antistoffer mot vevstransglutaminase (6). Måling av endomysiumantistoff anbefales fortsatt som en bekreftende metode når antistoffer mot vevstransglutaminase er forhøyet mer enn ti ganger, fordi spesifisiteten av denne metoden anses som noe høyere enn vevstransglutaminase $(3,6)$.

Vevstypene HLA-DQ2 og HLA-DQ8 disponerer for cøliaki, men finnes hos
$35-40 \%$ av befolkningen. Påvisning av disse genotypene kan derfor ikke påvise sykdom, men støtter diagnosen ved tvilstilfeller og er anbefalt i primærdiagnostikk dersom biopsi ikke blir tatt (3).

\section{Oppfølging}

Cøliaki finnes nå hos nesten $0,5 \%$ av norske barn (7), og andelen med kjent cøliaki er blitt tredoblet det siste tiåret (K. Størdal og medarbeidere, abstrakt ved World Congress

\section{«Cøliaki finnes nå hos nesten 0,5\% \\ av norske barn»}

of Pediatric Gastroenterology, Taipei 2012, upubliserte data). De fleste fastleger vil derfor se denne tilstanden oftere enn før. I retningslinjene anbefaler vi minst en kontroll hos barnelege 4-6 måneder etter diagnosen. Tidligere har årlig oppfølging hos barnelege vært regelen, men dersom symptomer er borte, og serologiske tester er normale, vil kontroll hvert andre år hos barnelege være tilstrekkelig. Vi mener også at fastleger kan ta over denne oppgaven dersom det ikke foreligger spesielle forhold. Lokale hensyn vil ha betydning for hvordan dette organiseres. En kontroll som inneholder måling av tilvekst, eventuelle symptomer og som suppleres med nødvendige blodprøver, vil vi anbefale hvert andre år til etter pubertet. Ved tegn til svikt i glutenfritt kosthold eller tvil omkring diagnosen, er ny henvisning til barneavdeling rimelig.

Nye retningslinjer for diagnostikk og oppfølging av cøliaki hos barn er nå publisert hos Helsebiblioteket. De er bearbeidet for norske forhold ved Norsk barnelegeforening og fagrådet i Norsk Cøliakiforening, og kan være et nyttig verktøy for alle leger som kommer i kontakt med denne tilstanden (8).

\section{Ketil Størdal}

ketil.stordal@fhi.no

Christine Olbjørn

Florin B. Vikskjold

Hans Kristian Holm

Ketil Størdal (f. 1966) er spesialist i pediatri, forsker ved Nasjonalt folkehelseinstitutt og overlege ved Barneavdelingen, Sykehuset Østfold.

Forfatter har fylt ut ICMJE-skjemaet og oppgir følgende interessekonflikter: Han har mottatt honorar for foredrag på medlemsmøter i Norsk Cøliakiforening og fått dekket reiseutgifter.
Christine Olbjørn (f. 1969) er overlege ved Barne- og ungdomsklinikken, Akershus universitetssykehus, spesialist i pediatri med barnegastroenterologi som spesialfelt, og ph.d.-stipendiat som forsker på kroniske tarmsykdommer hos barn.

Forfatter har fylt ut ICMJE-skjemaet og oppgir ingen interessekonflikter.

Florin B. Vikskjold (f. 1976) er spesialist i pediatri, med spesialkompetanse i pediatrisk gastroenterologi. Han er seksjonsoverlege ved Seksjon for poliklinikk og dagbehandling, Vestre Viken, Drammen, og sitter i styret for Barnelegeforeningens interessegruppe for pediatrisk gastroenterologi, hepatologi og ernæring. Forfatter har fylt ut ICMJE-skjemaet og oppgir ingen interessekonflikter.

Hans Kristian Holm (f. 1969) er spesialist i barnesykdommer. Han er seksjonsoverlege for Barneog ungdomspoliklinikken ved Sykehuset Innlandet, Lillehammer

Forfatter har fylt ut ICMJE-skjemaet og oppgir ingen interessekonflikter.

\section{Litteratur}

1. Meeuwisse GW, Weijers HA, Lindquist B et al. Diagnostic criteria in coeliac disease. Acta Paediatr Scand 1970; 59: 461-3.

2. Revised criteria for diagnosis of coeliac disease. Report of working group of European society of paediatric gastroenterology and nutrition. Arch Dis Child 1990; 65: 909-11.

3. Husby S, Koletzko S, Korponay-Szabó IR et al. European Society for Pediatric Gastroenterology. Hepatology, and Nutrition guidelines for the diagnosis of coeliac disease. J Pediatr Gastroenterol Nutr 2012; 54: 136-60.

4. Donat E, Ramos JM, Sánchez-Valverde F et al. Espghan 2012 guidelines for coeliac disease diagnosis: validation through a retrospective spanish multicentric study. J Pediatr Gastroenterol Nutr 2016; 62: 284-91.

5. Ludvigsson JF, Ansved P, Fälth-Magnusson K et al. Symptoms and signs have changed in Swedish children with coeliac disease. J Pediatr Gastroenterol Nutr 2004; 38: $181-6$

6. Lewis NR, Scott BB. Systematic review: the use of serology to exclude or diagnose coeliac disease la comparison of the endomysial and tissue trans glutaminase antibody tests). Aliment Pharmacol Ther 2006; 24: 47-54.

7. Størdal K, Bakken IJ, Surén P et al. Epidemiology of coeliac disease and comorbidity in Norwegian children. J Pediatr Gastroenterol Nutr 2013; 57 . 467-71.

8. Størdal K, Vikskjold FB, Holm HK. Retningslinjer for diagnostikk og oppfølging ved cøliaki hos barn. Oslo: Helsebiblioteket, 2015

Mottatt 25.10. 2015 og godkjent 25.1.2016. Redaktør Kaveh Halland Rashidi.

Publisert først på nett. 